\title{
Enabling a transformative dialogue in cases of enforced disappearances: voices of the families of the missing in the Monitoring Compliance with Judgments stage of the Inter-American Court of Human Rights
}

\author{
Mayra Nuñez Pastor ${ }^{1}$
}

\section{Key points of interest}

- Disappearance has social, political and cultural connotations that impact on the social fabric of communities and on families of victims. In this sense, in the course of the search process, families build social and political networks that transform their passive role as victims into active agents that use their presence in hearings before the Court to stress their claims and needs.

Keywords: Reparations, Victims, Inter-American Court of Human Rights, Enforced Disappearance.

\section{Introduction}

This research, through the analysis of the case-law of the Inter-American Court of Human Rights (IACtHR), seeks to shed light on the nexus between families of the missing' claims, their agency and State compliance with reparations. The IACtHR has a unique follow-up system in the area of reparations, where victims can directly address the judges

1) Ph.D. candidate at the Human Rights Institute of the University of Deusto. Correspondence to: mayra.npastor@deusto.es during hearings. This paper suggests that victims' participation - before and after the judgment - pervades the legal rigidity of international jurisdictions and contributes to a better understanding of reparations.

\section{Methodology}

The aim of this article is to analyse the importance of the participation of victims of enforced disappearance in the stage of supervision of compliance with judgments before the IACtHR. To this end, a desk review was conducted on legal sources (jurisprudence, rules of procedure of several international jurisdictions, treaties and national laws), and relevant doctrine.

Additionally, the information used to compile the list of cases of enforced disappearance listed in Table 1 was obtained through the database of the Inter-American Court, filtering the jurisprudence under the theme of "enforced disappearance". This first search provided the number of cases, (manually separated from Court orders related to provisional measures on cases before the Inter-American Commission of Human Rights, hereinafter IACmHR). Afterwards, the number of implemented or pending reparations in each of these cases was manually identified in the "Compliance with Judgment" section of the Court website. 
Table 1: Judgments of the IACtHR concerning enforced disappearances.

\begin{tabular}{|c|c|c|c|c|c|}
\hline \multirow[b]{2}{*}{ Case } & \multirow[b]{2}{*}{ Country } & \multirow[b]{2}{*}{ Year } & \multirow[b]{2}{*}{$\begin{array}{l}\text { Monitoring with } \\
\text { Compliance } \\
\text { Resolutions }\end{array}$} & \multicolumn{2}{|c|}{ Reparations } \\
\hline & & & & Implemented & $\begin{array}{c}\text { Pending } \\
\text { or partially } \\
\text { implemented }\end{array}$ \\
\hline $\begin{array}{l}\text { Godínez Cruz v. } \\
\text { Honduras }\end{array}$ & Honduras & 1989 & 1 & 1 & 0 \\
\hline $\begin{array}{l}\text { Velásquez Rodríguez v. } \\
\text { Honduras* }\end{array}$ & Honduras & 1989 & 1 & 1 & 0 \\
\hline $\begin{array}{l}\text { Caballero Delgado and } \\
\text { Santana v. Colombia }\end{array}$ & Colombia & 1997 & 7 & 2 & 2 \\
\hline Castillo Páez v. Perú^ & Perú & 1998 & 7 & 3 & 1 \\
\hline $\begin{array}{l}\text { Bámaca Velásquez v. } \\
\text { Guatemala }\end{array}$ & Guatemala & 1999 & 10 & 4 & 3 \\
\hline Blake v. Guatemala & Guatemala & 1999 & 5 & 1 & 1 \\
\hline Cesti Hurtado v. Perú^ & Perú & 2001 & 7 & 0 & 6 \\
\hline Trujillo Oroza v. Bolivia & Bolivia & 2002 & 5 & 7 & 2 \\
\hline $\begin{array}{l}19 \text { Merchants v. } \\
\text { Colombia }\end{array}$ & Colombia & 2004 & 7 & 5 & 8 \\
\hline $\begin{array}{l}\text { Molina Theissen v. } \\
\text { Guatemala }\end{array}$ & Guatemala & 2004 & 9 & 6 & 4 \\
\hline Gómez Palomino v. Perú & Perú & 2005 & 6 & 2 & 7 \\
\hline $\begin{array}{l}\text { Blanco Romero and } \\
\text { others v. Venezuela }\end{array}$ & Venezuela & 2005 & 1 & 0 & 10 \\
\hline $\begin{array}{l}\text { Goiburú and others v. } \\
\text { Paraguay }\end{array}$ & Paraguay & 2006 & 5 & 6 & 5 \\
\hline La Cantuta v. Perú & Perú & 2006 & 2 & 2 & 8 \\
\hline $\begin{array}{l}\text { Cantoral Huamaní and } \\
\text { García Santa Cruz v. } \\
\text { Perú }\end{array}$ & Perú & 2007 & 6 & 0 & 7 \\
\hline $\begin{array}{l}\text { Ticona Estrada and } \\
\text { others v. Bolivia }\end{array}$ & Bolivia & 2008 & 2 & 3 & 4 \\
\hline Tiu Tojín v. Guatemala & Guatemala & 2008 & 2 & 3 & 2 \\
\hline $\begin{array}{l}\text { Heliodoro Portugal v. } \\
\text { Panamá }\end{array}$ & Panamá & 2008 & 4 & 7 & 2 \\
\hline
\end{tabular}

* Year of the judgment on reparations; decision on the merits is registered in separate judgment. 


\begin{tabular}{|c|c|c|c|c|c|}
\hline \multirow[b]{2}{*}{ Case } & \multirow[b]{2}{*}{ Country } & \multirow[b]{2}{*}{ Year } & \multirow[b]{2}{*}{$\begin{array}{l}\text { Monitoring with } \\
\text { Compliance } \\
\text { Resolutions }\end{array}$} & \multicolumn{2}{|c|}{ Reparations } \\
\hline & & & & Implemented & $\begin{array}{c}\text { Pending } \\
\text { or partially } \\
\text { implemented }\end{array}$ \\
\hline $\begin{array}{l}\text { González and others } \\
\text { (Campo Algodonero) v. } \\
\text { México }\end{array}$ & México & 2009 & 1 & 8 & 6 \\
\hline $\begin{array}{l}\text { Radilla Pacheco v. } \\
\text { México }\end{array}$ & México & 2009 & 5 & 5 & 5 \\
\hline Anzualdo Castro v. Perú & Perú & 2009 & 2 & 1 & 9 \\
\hline $\begin{array}{l}\text { Ibsen Cárdenas e Ibsen } \\
\text { Peña v. Bolivia }\end{array}$ & Bolivia & 2010 & 1 & 3 & 5 \\
\hline $\begin{array}{l}\text { Gomes Lund and others } \\
\text { (Guerrilha do Araguaia) } \\
\text { v. Brasil }\end{array}$ & Brasil & 2010 & 1 & 2 & 9 \\
\hline $\begin{array}{l}\text { Chitay Nech and others } \\
\text { v. Guatemala }\end{array}$ & Guatemala & 2010 & 3 & 3 & 4 \\
\hline $\begin{array}{l}\text { Torres Millacura and } \\
\text { others v. Argentina }\end{array}$ & Argentina & 2011 & 2 & 1 & 4 \\
\hline $\begin{array}{l}\text { Contreras and others v. } \\
\text { El Salvador }\end{array}$ & $\begin{array}{l}\text { El } \\
\text { Salvador }\end{array}$ & 2011 & 2 & 6 & 7 \\
\hline Gelman v. Uruguay & Uruguay & 2011 & 2 & 4 & 7 \\
\hline $\begin{array}{l}\text { González Medina and } \\
\text { family v. Dominican } \\
\text { Republic }\end{array}$ & $\begin{array}{l}\text { Dominican } \\
\text { Republic }\end{array}$ & 2012 & 1 & 0 & 9 \\
\hline $\begin{array}{l}\text { García and family v. } \\
\text { Guatemala }\end{array}$ & Guatemala & 2012 & 1 & 2 & 9 \\
\hline $\begin{array}{l}\text { Gudiel Álvarez and } \\
\text { others (Diario Militar) v. } \\
\text { Guatemala }\end{array}$ & Guatemala & 2012 & 2 & 1 & 7 \\
\hline $\begin{array}{l}\text { Río Negro Massacre v. } \\
\text { Guatemala }\end{array}$ & Guatemala & 2012 & 4 & 2 & 9 \\
\hline $\begin{array}{l}\text { Afro-descendant } \\
\text { Communities displaced } \\
\text { from the Cacarica } \\
\text { River Basin (Operation } \\
\text { Genesis) v. Colombia }\end{array}$ & Colombia & 2013 & 1 & 1 & 7 \\
\hline $\begin{array}{l}\text { Osorio Rivera and family } \\
\text { v. Perú }\end{array}$ & Perú & 2013 & 3 & 4 & 6 \\
\hline
\end{tabular}




\begin{tabular}{|c|c|c|c|c|c|}
\hline \multirow[b]{2}{*}{ Case } & \multirow[b]{2}{*}{ Country } & \multirow[b]{2}{*}{ Year } & \multirow[b]{2}{*}{$\begin{array}{l}\text { Monitoring with } \\
\text { Compliance } \\
\text { Resolutions }\end{array}$} & \multicolumn{2}{|c|}{ Reparations } \\
\hline & & & & Implemented & $\begin{array}{c}\text { Pending } \\
\text { or partially } \\
\text { implemented }\end{array}$ \\
\hline $\begin{array}{l}\text { Rodríguez Vera et al. } \\
\text { (The Disappeared from } \\
\text { the Palace of Justice) v. } \\
\text { Colombia }\end{array}$ & Colombia & 2014 & 1 & 0 & 8 \\
\hline $\begin{array}{l}\text { Rochac Hernández and } \\
\text { others v. El Salvador }\end{array}$ & $\begin{array}{l}\text { El } \\
\text { Salvador }\end{array}$ & 2014 & 2 & 5 & 7 \\
\hline $\begin{array}{l}\text { Peasant Community of } \\
\text { Santa Barbara v. Perú }\end{array}$ & Perú & 2015 & 1 & 1 & 6 \\
\hline $\begin{array}{l}\text { Tenorio Roca and others } \\
\text { v. Perú }\end{array}$ & Perú & 2016 & 3 & 4 & 5 \\
\hline $\begin{array}{l}\text { Hacienda Brasil Verde } \\
\text { Workers v. Brasil }\end{array}$ & Brasil & 2017 & 1 & 2 & 3 \\
\hline $\begin{array}{l}\text { Vereda La Esperanza v. } \\
\text { Colombia }\end{array}$ & Colombia & 2017 & 1 & 2 & 7 \\
\hline $\begin{array}{l}\text { Vásquez Durand and } \\
\text { others v. Ecuador }\end{array}$ & Ecuador & 2017 & 0 & 1 & 5 \\
\hline $\begin{array}{l}\text { Gutiérrez Hernández and } \\
\text { others v. Guatemala }\end{array}$ & Guatemala & 2017 & 1 & 1 & 2 \\
\hline $\begin{array}{l}\text { Isaza Uribe and others v. } \\
\text { Colombia }\end{array}$ & Colombia & 2018 & 1 & 1 & 7 \\
\hline $\begin{array}{l}\text { Alvarado Espinoza and } \\
\text { others v. México }\end{array}$ & México & 2018 & 0 & 1 & 11 \\
\hline $\begin{array}{l}\text { Terrones Silva and others } \\
\text { v. Perú }\end{array}$ & Perú & 2018 & 1 & 1 & 8 \\
\hline $\begin{array}{l}\text { Munárriz Escobar and } \\
\text { others v. Perú }\end{array}$ & Perú & 2018 & 3 & 3 & 4 \\
\hline $\begin{array}{l}\text { Gómez Virula and others } \\
\text { v. Guatemala }\end{array}$ & Guatemala & 2019 & 0 & 0 & 4 \\
\hline TOTAL & 46 & & 133 & 118 & 252 \\
\hline
\end{tabular}

Own elaboration. Source: IACtHR Library. Available at https://biblioteca.corteidh.or.cr/ 


\section{Results}

\section{Victims}

A petition to regional or international human rights jurisdictions is the last opportunity for victims - in many cases, after decades of litigation - to find redress for mass human rights violations.

Therefore, it is essential for them to have a protagonist role in the proceedings, as the opportunity to express themselves about the suffering they experienced is itself a contribution to the recovery of their dignity (Minow, 2009 , p. 93). Moreover, families of the missing can bring to the attention of judges details of a context that they are unaware of: what victims highlight as relevant while describing their stories, which aspects of the disappearance are not being addressed by courts, what justice is for them and what they need to obtain redress.

Although human rights jurisdictions generally argue that they implement a "victim-centered approach", many victims only participate through their legal representatives. As established by Nagy, " $(t)$ here is a privileging of legal responses which are at times detrimentally abstracted from lived realities" (Nagy, 2008, p. 276). Moreover, depending on each case, victims' needs differ, change, and what they need to feel redressed can vary significantly depending on each context.

Victims of massive human rights violations have articulated different litigation strategies to obtain justice and reparations before different international forums when national authorities have failed to respond effectively to their needs and claims. As indicated by Jacqmin, "( $t$ )he struggles for the legalization of victims' claims often recurs to the narrative of human rights to achieve through the legal discourse what could not be gained through political debate" (Jacqmin 2017, page 1253).
Robins claims that legalism serves to interpret "thick issues", deeply rooted in the history and culture of a context, into "thin legal" concepts (Robins 2013, page 159). While the universality of human rights succeeds in bringing victims' claims into a neutral legal domain, in contrast, it encounters difficulties to address human rights embedded in unique social and political contexts (Jacqmin 2017, page 1254). Nonetheless, the experience of the IACtHR has evidenced that comprehensive interpretations in terms of legal rights serve to incorporate unique contextualised needs.

\section{The Inter-American Court of Human Rights}

The IACtHR examines cases that are submitted by the IACmHR, which in turn assesses whether a case should move to the contentious phase if there is no agreement on a friendly settlement between the State and the applicants or if the State has failed to comply with the provisions of such agreement. ${ }^{1}$

The institutional authority of both, the Court and the Commission, is such that their decisions and reports respectively, are taken into account by the highest courts in the region, prosecutors, political parties, legislative bodies and civil society organisations (Cavallaro \& O'Connell, 2020, p. 58).

Within the contentious phase, victims did not always enjoy the possibility of being part of the adversarial process in the Inter-American system. It is indeed since the entry into force of the Court's Fourth Rules of Procedure in June 2001 that individuals have had the opportunity to stand as autonomous parties with full legal capacity before the Court (Cançado Trindade, 2005, p. 33).

1 IACmHR, Rules of Procedure of the InterAmerican Commission on Human Rights, 28 November 2009, art. 44.3 and 45 . 
A key element in the Inter-American system are hearing sessions. At this stage of the process victims can address judges directly. By doing so, they put in words their experiences of trauma, grief, anger, sadness and helplessness (Karstedt 2016, page 50). The emotional content of the victims' testimonies during the hearings before the Court produces emotional responses from the audience, the representatives of the parties and even the judges (Karstedt 2016, page 50).

With this regard, hearings are crucial in cases of enforced disappearances. They illustrate the role of corporeality as power: disappearance not only implies the use of bodies as manifestations of the power of repressive structures (biopower). Families themselves use their own bodies as a mechanism of claim (biolegitimacy) (Ruiz-Estramil, 2020, p. 63). The presence of family members at the hearings is one of the very best demonstrations of this biolegitimacy: people literally position their bodies to underline the presence of those who cannot physically be there.

Families of victims of enforced disappearance are themselves victims. This has been established in the jurisprudence of the IACtHR. ${ }^{2}$

Family members need not only psychological support, but also other remedies to alleviate the pain they have experienced. Among these measures, one of the most urgent ones is the search for the remains of their loved ones, as well as the restoration of the public image of their loved ones. Regarding this last reparation, we can find the creation of projects related to the social causes that victims supported, the

2 IACtHR, Case 19 Merchants Vs. Colombia. Merits, Reparations and Costs. Judgment, 5 July 2004. Serie C No. 109, \$\$210, 212; IACtHR, Case Gómez Palomino Vs. Perú. Merits, Reparations and Costs. Judgment, 22 November 2005. Serie C No. 136, \$61. public recognition of the facts, the construction of monuments, among others.

\section{Victims'needs at the Monitoring Compliance} with fudgments stage

Judgments may include reparation orders, which are designed to restore the right injured or compensate for the harm suffered by the victims. Reparations are regulated in article 63 of the American Convention on Human Rights (ACHR) and the fulfillment of these reparations are addressed by international jurisdictions in a posterior phase to the judgment: the monitoring with judgment stage. ${ }^{3}$

In the Inter-American system, the monitoring process is based on the periodic submission of reports by the State and the representatives of victims concerning progress in the implementation of reparations. The Court can request the IACmHR to present its own observation. In this stage, the Court might require information from third parties and conduct hearings. Once the Court has gathered information from the parties, it passes a decision regarding the state of compliance. ${ }^{4}$

Notably, the IACtHR sometimes conducts visits to States to monitor the stage of compliance of the contentious case. In the context of the El Mozote case, the Court conducted a visit to El Salvador in 2018 to assess compliance with the reparations ordered in the judgment (Alessandri, 2020, p. 4). A private hearing was held during the visit so that victims could express their main concerns about the implementation of the decision. ${ }^{5}$

3 American Convention on Human Rights, 22 November 1969, entry into force 18 July 1978 , Art. 63.

4 IACtHR, 'Rules of Procedure of the InterAmerican Court of Human Rights', approved by the Court on 30 June 1980 and last modified on 28 November 2009, Art. 69(3) and 69(4).

5 IACtHR, Massacres of El Mozote and 
Currently, the IACtHR is monitoring compliance in 222 cases. $^{6}$ Many of these proceedings have been open for more than twenty years. Although most of the States do not comply with every reparation ordered by the Court, the implementation of many of these measures have had a profound impact on local courts and national legislative bodies. The actions that the State undertakes in virtue of that judgment produce root changes at the local level, particularly in terms of internalisation of international standards by local courts (Huneeus, 2011, p. 505).

Nonetheless, States often resist the implementation of reparations, specially those that affect national policies and promote structural changes (Bell, Campbell, \& Aoláin, 2004, p. 308). For instance, in April 2019, the governments of Chile, Argentina, Colombia, Paraguay and Brazil sent a communication to the Executive Secretary of the IACmHR to raise their concerns about the broad scope of the reparations awarded in contentious cases, highlighting at the same time the subsidiary nature of the Inter-American system (Chilean Ministry of Foreign Affairs, 2019). The communication requested the IACHmR to respect the margin of appreciation that States enjoy concerning measures to guarantee and promote human rights. Furthermore, these States expressed that the Court should take into consideration the principle of proportionality in relation to the extent of the reparations and the respect to the national constitutional order (Chilean Ministry of Foreign Affairs, 2019).
To illustrate the importance of the participation of victims in the monitoring stage of the Court, the following section will address hearings in the Monitoring with Compliance stage of the Molina Theissen case.

A case study on the Monitoring with compliance stage: Molina Theissen v. Guatemala

The case refers to the illegal detention and enforced disappearance of Marco Antonio Molina Theissen in 1981 in the city of Guatemala, in the context of an authoritarian regime and civil war. His sister Emma was part of the Patriotic Labor Youth group ("Juventud Patriótica del Trabajo"), an organisation linked to the Guatemalan Labor Party (PGT). ${ }^{7}$ On September 27, 1981 she was illegally detained by the Armed Forces and remained for nine days in a military facility in Quetzaltenango. ${ }^{8}$ She was subjected to physical and psychological torture. By the ninth day, she was so thin she managed to release herself from her handcuffs and escaped. ${ }^{9}$ The next day, October 6, 1981 two persons carrying automatic weapons arrived at Molina Theissen's home, searched the house and kidnapped the youngest of the Molina Theissen siblings, Marco Antonio, who was fourteen years old. ${ }^{10}$ The boy's fate remains unknown. The detention and subsequently enforced disappearance of Marco Antonio were perpetrated by the Armed Forces, allegedly in revenge for Emma's escape. ${ }^{11}$

In this period, enforced disappearance was a common practice by security forces, justi-

surrounding areas v. El Salvador. Compliance with judgment order, 18 November 2018, \$\$5-6.

6 IACtHR, Cases at the Monitoring Compliance with Judgment Stage, available at https://www. corteidh.or.cr/casos_en_supervision_por_pais. cfm?lang=en

7 IACtHR, Case of Molina Theissen v. Guatemala. Merits. Judgment of May 4, 2004. Series C No. 106, $\$ 40$ (9)(iv).

8 Ibid.

9 Ibid.

10 Ibid, $\$ \$ 40(10)-40(11)$.

11 Ibid, $\$ 40(12)$. 
fied by the government as a necessary measure to fight "insurgent" individuals. ${ }^{12}$ Under the "National Security Doctrine" anyone who dared to question the government was targeted as a "subversive person". ${ }^{13}$

During the proceedings before the IACtHR, the State recognised its responsibility and acknowledged the facts. Consequently, the Court found Guatemala internationally responsible for the violation of article 4 (the right to life), article 5.1 and 5.2 (right to humane treatment), article 7 (right to personal liberty), article 8 (right to a fair trial), article 17 (right to family), article 19 (rights of the child) and article 25 (judicial protection) in connection to articles 1.1 (obligation to respect rights) and article 2 (domestic legal effects) of the American Convention on Human Rights, and articles I and II of the Inter-American Convention of Enforced Disappearances of persons in relation to the detention and enforced disappearance of Marco Antonio. The Court also found the State responsible of the violation of article 5.1 and 5.2 (the right to humane treatment), article 8 (right to fair trial), article 17 (right to family) and article 25 (judicial protection) in connection to articles 1.1 and 2 of the ACHR in relation to Marco Antonio's family: her sisters Emma, María Eugenia and Ana Lucrecia and her mother Emma Theissen Alvarez De Molina. ${ }^{14}$

The judgment on reparations was issued in $2004 .{ }^{15}$ Since then, progress concerning compliance by the Guatemalan State has been slow but constant, largely due to the tireless work of

12 Ibid., $\$ 40(1)$.

13 Ibid., $\$ 40(2)$.

14 Ibid., \$43-44.

15 IACtHR, Case of Molina Theissen v. Guatemala. Reparations and Costs. Judgment of July 3, 2004. Series C No. 108, \$106. victims and human rights organisations, both locally and regionally.

By the time that the first compliance with judgment resolution was issued in 2007, the State had fulfilled its obligations regarding reparations on monetary compensation (2004), a public act recognizing the violations determined in the judgment (2006) and the naming of a school as "Martyr Marco Antonio Molina Theissen", where a commemorative plaque was placed (2006). ${ }^{16}$ The Court requested the State to submit regular reports concerning the implementation of the rest of the reparations. Two years later, the reparation regarding the publication of part of the judgment was considered fulfilled. ${ }^{17}$

It is worth mentioning that, while considering the overall jurisprudence of the Court, reparations on compensations and formal apologies are the most implemented ones, whereas measures related to structural issues or individual prosecutions remain largely unobserved. In the cases of enforced disappearance, measures related to finding the remains of those missing are largely ignored by governments. A study conducted in 2019 revealed that rates of State compliance with measures such as monetary compensation, publication of judgments and acts of acknowledgment were between $63 \%$ and $80 \%$, while structural and far-reaching reparations, such as prosecutions or changes to legislation presented rates of compliance between 3\% and 31\% (Pérez Liñán, Schenoni, \& Morrison, 2019, p. 17). These types of measures implies higher levels of political commitment and resources.

16 IACtHR, Case of Molina Theissen v. Guatemala. Compliance with judgment order, 10 July 2007, November 2018, \$\$5-7, 15.

17 IACtHR, Case of Molina Theissen v. Guatemala. Compliance with judgment order, 16 November 2009, operative paragraph 1 . 
The importance of localizing Marco Antonio's remains is essential for the family to mourn their loss. In this regard, Ana Lucrecia Molina Theissen stated: "I am going to dedicate the rest of my life to find my brother and to tell what happened." 18

The four measures that the State has not comply with are structural: (i) finding Marco Antonio's remains, (ii) the creation of an institute for the safeguarding of genetic information pursuant to find missing persons, (iii) the investigation of the facts in order to identify, try and punish those responsible of the enforced disappearance and (iv) to enact legislation to search persons who are presumed dead as a consequence of enforced disappearance.

In its resolution of November 24, 2015, the Court established that:

\section{(...) it should be noted that, although the} facts of this case began 34 years ago and the Court's sentence was issued eleven years ago, the criminal proceedings are still in the investigation stage and the whereabouts of Marco Antonio Molina Theissen and the location and identification of his remains continue to be unknown. ${ }^{19}$

Disappearance makes the social, political and cultural fabric more complex and at the same time creates new dynamics. The existence of the disappeared is possible through

18 IACtHR, Case of Molina Theissen v. Guatemala. Submission of requests, arguments and evidence submitted by the Representatives of the Alleged Victims, p. 81 (author's translation).

19 IACtHR, Case of the Members of the Village of Chichupac and Neighboring Communities in the Municipality of Rabinal, Case of Molina Theissen and 12 other cases against Guatemala. Compliance with judgment order, 12 March 2019, $\$ 88$ (personal translation). those who demand his or her return. In this way, the disappeared exists as long as someone is looking for them (Irazuzta, 2020, p. 96).

After years of perseverance by the Molina Theissen family and human rights organisations, on March 2017 a criminal trial was initiated against Francisco Gordillo, Edilberto Letona, Hugo Zaldaña, Manuel Callejas and Benedicto Lucas García, the five former high ranked military officers accused of the enforced disappearance of Marco Antonio (elPeriodico, 2017). This was a historical trial, as it was the first time that highly ranked commanders - persons with powerful political and economic influence- were tried for having committed international crimes by the Guatemalan Justice System. It was a long process and the Molina Theissen family suffered countless situations of harassment and de-legitimization strategies carried out by conservative sectors of the society and the political elite. The judgment was passed in May 2018. ${ }^{20}$ Except for Edilberto Letona, the accused were found guilty of crimes against humanity for the illegal detention and torture of Emma Guadalupe Molina Theissen and the illegal detention and enforced disappearance of Marco Antonio Molina Theissen.

They were sentenced to 20 and 25 years of imprisonment, respectively. In its 1075 judgment, the Court analysed the facts and the law taking into consideration international legal standards and the jurisprudence of the IACtHR. $^{21}$

As the accused have appealed the case, the reparation related to investigation and prose-

20 First Court of Criminal Sentencing, Drug Trafficking and Crimes against the Environment of High Risk Group “C”, Judgment C-010771998-00002, \$1067-1068.

21 Ibid., $\$ \$ 257,265,1060$. 
cution is still considered as partially fulfilled by the IACtHR. ${ }^{22}$

On January 25, 2018 a legislative initiative was presented to the Plenary of the Congress to reform the National Reconciliation Law from 1996, created in the context of the Peace Agreement process in the aftermath of the civil war. ${ }^{23}$ The reform - called Initiative 5377- pretends to grant broad amnesties to those who committed crimes against humanity, war crimes and genocide. ${ }^{24}$

One of the most worrying details of the proposed bill was that article 5 established that every person that was currently detained or imprisoned because of crimes committed in the context of the civil war (as in the Molina Theissen case) had to be released within 24 hours after the bill was approved by the Congress. Furthermore, every ongoing investigation had to be immediately closed and archived. If public servants as well as prison guards did not comply with the law within this period of time, they "[would] be prosecuted for incur malicious delay, denial of justice and illegal detention." 25

The Guatemalan Congress is unicameral. A legislative process requires a bill to be discussed and approved in three debates. Once the draft is approved after the third debate, the law is passed. ${ }^{26}$

The proposal was approved in the first debate on 17 January 2019 and in the second

22 IACtHR, Case of Molina Theissen v. Guatemala. Compliance with judgment order, 16 November 2009, operative paragraph 1(2).

23 Congress of Guatemala, "Bill to reform the decree number 145-96, 'National Reconciliation Law", Initiative 5377.

24 Ibid., art. 3.

25 Ibid., art. 5.

26 Political Constitution of the Republic of Guatemala, Legislative Agreement 18-93, Art. 176. debate on 6 March 2019.27 The rapid discussion and approvals of the project caused severe concern among families of victims of the armed conflict as well as national and international human rights organisations. There was a tangible possibility that impunity for those responsible for serious human rights violations would be guaranteed by law.

In this dramatic context, the Molina Theissen family requested an urgent public hearing to the IACtHR in the supervision of compliance stage of the case. In a race against time, the Court scheduled a public hearing on Monday, March 11, 2019, just two days before the third and final debate was scheduled by the Guatemalan congress (Congress of Guatemala, Department of Legislative Information, 2019). The Court summoned the victims, representatives of the State as well as agents of the IACmHR.

The implications of the possible approval of the Initiative were worrisome. The Molina Theissen family was deeply concerned that the justice they finally obtained at the national level less than a year ago was going to vanish as the convicted persons were going to be released. Furthermore, they felt anguish as this could also impact negatively on the current investigation to find the location of Marco Antonio's remains.

With these priorities in mind, the representatives of the victims agreed that the main part of their exposition during the hearing should be carried out by the victims themselves. Consequently, the judges listened to Marco Antonio's mother and his three sisters. Ana Lucrecia Molina Theissen stated:

27 Congress of Guatemala, 'Legislative consultation, status of bills.', available at https://www.congreso. gob.gt/ 
I have been immersed in an endless, tortured grief, (...). Accepting his death without death, without seeing his body to prove it (...). After repeated demands to the State to comply with the reparations ordered by this honorable Court (...), we achieved the conviction of four former highly-ranked military officers (...) The current draft bill constitutes an additional offense for Marco Antonio, Emma, my family and the tens of thousands of victims of State terrorism. $^{28}$

With this regard, the representatives of the victims requested the Court to order the Guatemalan State to develop a search program to find the victim's mortal remains. ${ }^{29}$ After listening to the victims and their representatives, one of the judges addressed the IACmHR and the victims and asked "how can we contribute to the safety of victims while working to obtain State compliance in this case?" 30 This kind of interaction during the hearing illustrates the dynamic nature of this stage of the proceedings: there is a fluid dialogue between representatives of the IACmHR, victims, their representatives and the judges themselves to prevent State decisions that might affect the rights of the victims and the fulfillment of the reparations ordered.

In addition, one of the judges addressed the representative of the Guatemalan State in order to obtain information regarding the immediate effects of the law, if approved, on people already convicted for mass crimes. The Guatemalan diplomat could not deny the impact of the law if approved and avoided answering directly to this question. ${ }^{31}$

The coordinated actions between different human rights institutions and civil society to prevent State policies detrimental for victims of mass human rights violations involved regional and international actors. On the same day that this hearing was taking place, the UN Special Rapporteur on Truth, Justice, Reparations and Guarantees of Non-Recurrence and other UN Special Rapporteurs issued a press release in which he stated that:

The approval of these reforms would seriously affect victims' rights to justice, truth, reparation and guarantees of non-repetition. It could also lead to reprisals and attacks against victims, judges, prosecutors, lawyers, plaintiffs, witnesses, experts and others involved in human rights trials, putting their own safety and that of their families at risk (OHCHR, 2019).

Notably, and for the first time in its history, the IACtHR issued a Compliance with Judgment order in less than 24 hours (including thirteen other Guatemalan cases that would be also affected by the law). It requested the State to "interrupt the legislative process of bill 5377" and to archive it. ${ }^{32}$ Moreover, it established that:

The Court considers that the requirement of extreme gravity is met as the approval of this law would have a negative and ir-
28 IACtHR, Case Molina Theissen v. Guatemala. Public Hearing on Supervision of Compliance with Judgment. 11 March 2019, Testimony of Ana Lucrecia Molina Theissen. Min. 00:19:10 (personal translation).

29 Ibid., Min. 33.20 (personal translation).

30 Ibid., Min. 1.31.00.
31 Ibid., Min. 1:55:30. The representative of the State stated "I can't speculate on a law that hasn't been approved".

32 IACtHR, Case of the Members of the Village of Chichupac and Neighboring Communities in the Municipality of Rabinal, Case of Molina Theissen and 12 other cases against Guatemala, 12 March 2019, operative paragraph 2 . 
reparable impact on the right to access justice for the victims of the 14 cases in which this international tribunal has issued fudgments concerning serious violations committed or alleged to have occurred in the internal armed conflict. ${ }^{33}$

The morning after, the Guatemalan Congress had scheduled the third and final debate needed to approve the Initiative 5377. At the Congress entrance, members of human rights organisations distributed copies of the IACtHR resolution to all the deputies so that they would be aware that the international community was strictly monitoring the legislative session of that day. The bill was not discussed that day or any other until today. The third remaining debate and vote for its approval is not part of the agenda of the Guatemalan Congress so far.

Apart from this resolution, the Court issued a second one on the Molina Theissen case, where the reparation regarding the location of the remains of Marco Antonio was addressed. It stressed the importance of recovering the victims' remains in cases of enforced disappearances:

The Court emphasizes the importance of the fulfilment of this measure since it provides moral satisfaction to the victims and is indispensable in the mourning process. In the present case, Marco Antonio's mother and sisters have expected information on their whereabouts for over 37 years. ${ }^{34}$

It quoted parts of the testimonies given by the victims during the hearing and requested the Guatemalan State to submit detailed information regarding the search plan to locate his remains. ${ }^{35}$

This case illustrates the undeniable positive effect of the active participation of victims in these types of legal proceedings, specially in public hearings. This feature allows for judges to obtain first hand information concerning victims' needs and the current state of the implementation of reparations. Thus, the testimonies of the Molina Theissen family were crucial to demonstrate the urgent need to find Marco Antonio and to interrupt the legislative process that would grant impunity to those responsible of the crimes. In cases of enforced disappearances, this kind of measure is key so that victims can obtain redress. Lucrecia Molina Theissen wrote:

The silence about our child's whereabouts has not been broken. Marco Antonio is still missing. Our grief is permanent, painfully inconclusive. We will not give up; we will keep looking for him (Molina Theissen, 2020, p. 5).

\section{Discussion and conclusion}

The IACtHR practice shows that the active participation of victims in the proceedings, especially in hearings where victims can speak directly to the judges, is one of the most effective mechanisms for translating unique needs into adequate and effective rights and reparations.

The case study as well as other cases within this jurisdiction reveals that the most requested form of reparation by families of victims of enforced disappearance is the recovery of the remains of their loved ones. ${ }^{36}$ The
33 Ibid., \$36.

34 IACtHR, Case of Molina Theissen v. Guatemala. Compliance with Judgment order, 14 March $2019, \$ 42$.
35 Ibid., $\$ 44$.

36 IACtHR, Case Gelman v Uruguay. Submission of requests, arguments and evidence by the Representatives of the Alleged Victims, 24 April 
IACtHR, through the constant evolution of its regulations and practices, is offering more opportunities for victims to express their views. In the end, their very participation itself is a form of recognition.

This being said, reparations have an impact that often transcends the contentious case. The case study demonstrated how the coordinated efforts of the victim's family and of civil society relied on the Court's Monitoring with Judgments hearing to prevent the enactment of a nationwide law that sought to promote impunity in the country.

As Table 1 illustrates, although certain reparations measures were complied with (118), the number of non-implemented remedies remains higher (252). The particularities of enforced disappearance, as the pacts of impunity and silence that remains in many Latin American contexts, result in the fact that the search for disappeared persons continues to be the least implemented reparation.

Although there are major challenges posed by States resisting compliance with reparations, the IACtHR's openness to use comprehensive approaches in cases of enforced disappearances, allows victims and human rights organisations to articulate national and international responses to this type of crime and beyond. As it was stated by certain families of the disappeared, their suffering does not end once a judgment is delivered. Monitoring with Compliance stage is a second phase of a continuous struggle. Without the remains, death is still present; hearings represent an opportunity to provide physical presence to those disappearance.

\section{References}

Cançado Trindade, A. A. (2005). El Reglamento de la Corte Interamericana de Derechos Humanos y su Proyección hacia el Futuro: La Emancipación del Ser Humano Como Sujeto del Derecho Internacional. In M. E. Ventura Robles \& A. A. Cançado Trindade (Eds.), El futuro de la Corte Interamericana de Derechos Humanos (pp. 21-118).

Minow, M. (2009). Between vengeance and forgiveness. facing history after genocide and mass violence (Nachdr). Beacon Press.

Nagy, R. (2008). Transitional Justice as Global Project: critical reflections. Third World Quarterly, 29(2), 275-289. DOI: $10.1080 / 01436590701806848$

Pena, M., \& Carayon, G. (2013). Is the ICC Making the Most of Victim Participation? The International fournal of Transitional fustice, 7(3), 518-535. DOI: $10.1093 / \mathrm{ijt} /$ ijt021

Alessandri, P. S. (2020). The Role of the InterAmerican Court of Human Rights in Monitoring Compliance with Judgments. Fournal of Human Rights Practice, 178-184. DOI:10.1093/jhuman/ huaa018

Bell, C., Campbell, C., \& Aoláin, F. N. (2004). Justice Discourses in Transition. Social E Legal Studies, 13(3), 305-328. DOI:10.1177/0964663904044997

Chilean Ministry of Foreign Affairs. (April 23, 2019). Press Release of the Ministry of Justice and Human Rights on the Inter-American System of Human Rights. Retrieved from https://minrel.gob.cl/comunicado-de-prensaministerio-de-relaciones-exteriores-ministerio-de/ minrel/2019-04-23/105105.html

Congress of Guatemala, Department of Legislative Information. (2019). Agenda (March 13, 2019). Retrieved from Congress of Guatemala website: https://www.congreso.gob.gt/ assets/uploads/info_legislativo/orden_del_ dia/1552338889_13.03.2019.2.pdf

elPeriodico. (3 March, 2017). Benedicto Lucas va a juicio por desaparición y violación. elPeriodico. Retrieved from https:/elperiodico.com.gt/ nacion/2017/03/03/nota-4-23/

Huneeus, A. (2011). Courts Resisting Courts: Lessons from the Inter-American Court's Struggle to Enforce Human Rights. Cornell International Law fournal, 44(3), 493-534.

Irazuzta, I. (2020). Searching is to investigate: search practices in the world of the disappearance in Mexico. Sociología y tecnociencia, 10(1), 94-116. doi:10.24197/st.1.2020.94-116

Molina Theissen, L. (2020). Until We Find Marco Antonio. Fournal of Human Rights Practice, 1-6. DOI:10.1093/ihuman/huaa023

OHCHR. (3 November, 2019). Guatemala 
Congress must not pass "amnesty" bill for rights violations, say UN experts. Retrieved from OHCHR website: https://www.ohchr. org/SP/NewsEvents/Pages/DisplayNews. aspx? NewsID $=24300$ \&LangID $=\mathrm{E}$

Pérez Liñán, A., Schenoni, L., \& Morrison, K.

(2019). Time and Compliance with International Rulings: The Case of the Inter-American Court of Human Rights. Mpil Research Paper Series. Max Plack Institute, 2019-17. DOI:10.2139/ ssrn.3463105

Ruiz-Estramil, I. B. (2020). Biopolítica y biolegitimidad: Apuntes desde el tratamiento del asilo y refugio. Ámbitos. Revista de Estudios de Ciencias Sociales y Humanidades, (44), 57-67. DOI: $10.6018 /$ daimon.465721

\section{Acknowledgements}

This article is part of the final dissertation submitted to obtain the master's degree in Transitional Justice, Human Rights and the Rule of Law of the Geneva Academy of International Humanitarian Law and Human Rights. The author appreciates the invaluable comments and contributions of Professor Frank Haldemann. 